\title{
Evaluation of distant results after lamivudine discontinuation in children with chronic hepatitis B
}

\author{
Joanna Pancewicz, Oksana Kowalczuk, Lech Chyczewski \\ Department of Clinical Molecular Biology, Medical University of Bialystok, Poland
}

\begin{abstract}
The aim of this study was to estimate distant results after discontinuation of long term lamivudine treatment in children with chronic hepatitis B. Furthermore, the emergence of HBV polymerase gene variants in YMDD motif during therapy was examined. Additionally, the most commonly occurring type of mutation in the polymerase YMDD region were investigated. The study involved $27 \mathrm{HBeAg}$ positive children with chronic hepatitis B. Children included to lamivudine therapy were previously treated without effects with interferon $\alpha$.
\end{abstract}

Key words: HBV DNA, lamivudine resistance, polymerase gen, YMDD motif

\section{Introduction}

Although efficient vaccines, new nucleoside analogs are available, chronic hepatitis B (HBV) infection is still a major health problem worldwide [1]. Children infected early in life who have indication of viral replication are at the high risk for development of progressive liver disease and are a major source of infection in others [2]. Treatment options for children are still limited. The goal of treatment is to prevent the progression of chronic hepatitis B to long-term complications, such as cirrhosis and hepatocellular carcinoma, that can result in death [3].

Lamivudine was the first oral antiviral therapy approved for the treatment of CHB [4]. Molecular mechanism of resistance in HBV genome is well known but the optimal length for children's treatment with lamivudine required to achieve a durable virological response has not been established [5].

Lamivudine resistance is due to the selection of HBV mutants that undergo mutation in the HBV DNA polymerase gene. The $\mathrm{C}$ domain of the polymerase gene has a common tyrosine-methionine-aspartateaspartate (YMDD) motif essential for polymerase activity. This conserved motif is involved in nucleotide binding in the catalytic site of the polymerase [6].

Correspondence: J. Pancewicz, Dept. of Clinical Molecular Biology, Medical University of Białystok, Waszyngtona 13 Str. 15-276 Bialystok, Poland;

e-mail: joannapancewicz@yahoo.co.uk

\section{Material and methods}

Sera from 27 children with chronic hepatitis B were investigated in this study. Serum samples were sequentially collected from children - before, during, after lamivudine treatment and six months after lamivudine discontinuation. All patients had active inflammation in the liver and $\mathrm{HBeAg}$ presence in serum. Before lamivudine treatment, children were treated with interferon alpha in 3MIU 3 times a week for 20 weeks. Lamivudine therapy started after unsuccessfully INF alpha treatment due to schedule: $3-4 \mathrm{mg} / \mathrm{kg}$ body weight 1 daily for 1,5 year (max dose was $100 \mathrm{mg} / 24 \mathrm{~h}$ ).

HBV DNA extraction. DNA was isolated from children's sera with Gen Elute ${ }^{\mathrm{TM}}$ Mammalian Genomic DNA Miniprep Kit (Sigma, USA). Amplification of virus's reverse transcriptase region was achieved by PCR and nested PCR in Gene Amp PCR System 2400 from Applied Biosystems. Primers were complementary to conservative part of genome (sense 5'-AG GGG AGG AGA TTA GGT TAA-3' antisense 5'-AGG AGT GCG AAT CCA CAC TC-3'). PCR reaction included: $200 \mathrm{mM}$ dNTPs, 0.4 $\mathrm{mM}$ all primers, $1.5 \mathrm{mM} \mathrm{MgCL2}, 1.0 \mathrm{U}$ Taq polymerase (Sigma). Thermal profile of PCR: $96^{\circ} \mathrm{C}$ for $30 \mathrm{~s}$, in $57^{\circ} \mathrm{C}$ for 60 $\mathrm{s}$ and in $72^{\circ} \mathrm{C}$ for $60 \mathrm{~s}$ (40 cycles).

Detection of mutation in YMDD region. Mutation in YMDD region were detected by sequencing and RLFP used as a screening method. Before of sequencing reaction, the part of gene of virus's polymerase with rt204 became duplicated in single PCR or nested-PCR reaction in dependence of HBV-DNA concentration in studied samples. Amplification were performed in mixture contain $10 \mathrm{mM}$ Tris- $\mathrm{HCl} \mathrm{pH} 8.3,50 \mathrm{mM} \mathrm{KCl}, 1.5 \mathrm{mM}$ $\mathrm{MgCl}_{2}, 0.2 \mathrm{mM}$ each dNTP, $0.5 \mathrm{mM}$ each primer, $1 \mathrm{U}$ DNA polymerase and $5 \mathrm{ml}$ of solution of DNA. Amplification were performed with primer 840 (5'-ACC CCA TCT TTT TGT TTT GTT AGG-3') and 377 primer (5'-GGA TGT GTC TGC GGC GTT T-3'). In nested-PCR reaction external primer 12F (5'-AGA CTC GTG GTG GAC TTC TCT-3') and 5RC (5'-CAA AAG 
AAA ATT GGT AAC AGC GGT A-3'), as well as internal primers 840 and 377 were used (thermocycler GeneAmp PCR System 2400 Applied Biosystems, USA) PCR were performed according to following thermal profile: $5 \mathrm{~min}$ in $94^{\circ} \mathrm{C}, 40$ cycles for $30 \mathrm{~s}$ in $94^{\circ} \mathrm{C}, 30 \mathrm{~s}$ in $55^{\circ} \mathrm{C}$ and $60 \mathrm{~s}$ in $72^{\circ} \mathrm{C}$ and $5 \mathrm{~min}$ in $72^{\circ} \mathrm{C}$. Cleaning of PCR products were prepared with reagents Clean-Up (A\&A Biotechnology, Poland).

Reaction of sequence were executed, using Big Dye Apprentice Termistor Cycle Sequencing Ready Reaction Kit (Applied Biosystems, USA). Sequenced products were cleaned by Ex Terminator Kit (A\&A Biotechnology, Poland).

The sequencing was performed ABI PRISM 377 (Applied Biosystems, USA).

HBV-DNA quantification. In order to HBV-DNA sequences in patient's sera, PCR method with conserved region primers was performed. Thermal cycling was achieved using the following conditions: initial incubation at $96^{\circ} \mathrm{C}$ for $120 \mathrm{~s}$, and then 40 cycles in $94^{\circ} \mathrm{C}$ for $30 \mathrm{~s}, 50^{\circ} \mathrm{C}$ for $30 \mathrm{~s}$ and $72^{\circ} \mathrm{C}$ for $60 \mathrm{~s}$.

HBV-DNA concentration were detected in sera by real-time PCR based on TaqMan chemistry. Amplification was performed in $25 \mu \mathrm{l}$ reaction mixture containing $2 \times$ TaqMan Universal Master Mix (Applied Biosystems) with uracil N'-glycosylase, 30 pmol of forward primer, $30 \mathrm{pmol}$ of reverse primer, $30 \mathrm{pmol}$ TaqMan probe (5'-FAM) and $5 \mu 1$ of isolated DNA. After incubation for 2 minutes at $50^{\circ} \mathrm{C}$, which enables uracil N'-glycosylase to inactivate possible contaminating amplicons, incubation for $10 \mathrm{~min}$ at $95^{\circ} \mathrm{C}$ allowed AmpliTaq Gold polymerase to activate and inactivate the uracil N'-glycosylase. The PCR cycling program consisted of 45 two-step cycles of $15 \mathrm{w}$ at $95^{\circ} \mathrm{C}$ and 60 s at $60^{\circ} \mathrm{C}$.

Analysis of raw data was done with the Sequence Detector V1.6.3 software (PE Biosystems). Data were collected at the annealing step $\left(60^{\circ} \mathrm{C}\right)$ of every cycle, and the threshold cycle (Ct) for each sample was calculated by determining the point at which the fluorescence exceeded the threshold limit, which was set at $0.04 \mathrm{U}$. The standard curve was calculated automatically by plotting the $\mathrm{Ct}$ values against each standard of known concentration. For preparation of the external standards an international reference VQC plasma preparation panel (CLB) containing well-characterized HBV-DNA levels was used. Sample copy numbers were calculated by interpolation of the experimentally determined standard curve. The detection limit of this system was as few as $10 \mathrm{HBV}-\mathrm{DNA}$ copies/ml of serum. A linear standard curve was obtained between 10 and $10^{8}$ DNA template copies/reaction.

\section{Results}

\section{Dynamic range of $H B V D N A$ during 2 years of lamivudine therapy and six months after lamivudine discontinuation based on PCR and real time PCR}

Before lamivudine treatment all children had high $\left(10^{8}-10^{9}\right.$ copies $\left./ \mathrm{ml}\right)$ serum HBV DNA level. Children's samples were divided into two groups based on the presence of HBV DNA level after two years of lamivudine treatment.

Group I included $18(66.7 \%)$ children's sera with HBV DNA between $10^{4}-10^{9}$ copies $/ \mathrm{ml}$ after 2 years of lamivudine treatment, whereas group II- $9(33.35 \%)$ included children's sera with HBV DNA below $10^{3}$ copy $/ \mathrm{ml}$.

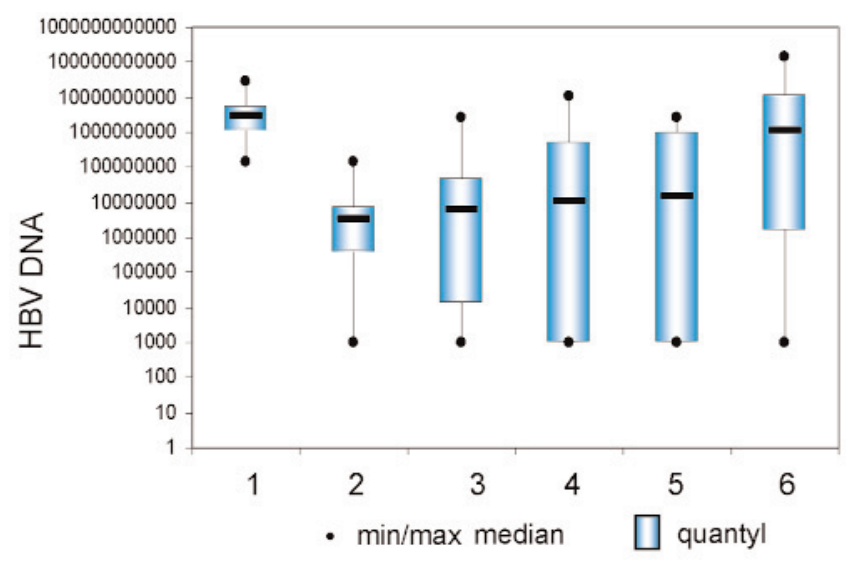

Fig. 1. Average concentration of HBV DNA during and after lamivudine treatment (logarytmic graph) in total number of patients: 1 - before treatment; 2 - half a year after treatment; 3 one year after treatment; 4 - year and a half after treatment; 5 two years after treatment; 6 - six months after lamivudine discontinuation.

After half year of lamivudine therapy all examined patients had lower HBV DNA level when compared to level of HBV DNA before treatment $(\mathrm{p}=0.00001)$. Four (14.8\%) patients (group II) had HBV DNA below $10^{3}$ copies $/ \mathrm{ml}$. Average HBV DNA concentration for all patients at that time was as high as $1.0 \times 10^{7}$ copies $/ \mathrm{ml}$.

Next 6 months of lamivudine therapy showed that HBV DNA level increased in $13(48.2 \%)$ patients $(12$ from group I, 1 - group II) when compared to HBV DNA level after half year of treatment $(\mathrm{p}=0.13)$.

In other $12(44.4 \%)$ children's samples $(6-$ from group I and 6 - group II) we observed that HBV DNA decreased, however in $2(7.4 \%)$ samples (group II) DNA level did not change. The average concentration of HBV DNA at that time of treatment was $1.53 \times 10^{8}$ copies $/ \mathrm{ml}$. Therefore, next half year of treatment showed that in $13(48.2 \%)$ children from group I HBV DNA increased when compared to HBV DNA level before 6 months $(\mathrm{p}=0.02)$, but $10(37.03 \%)$ of 27 patients ( 4 - group I, 6 - group II) had lower HBV DNA level. In $4(14.8 \%)$ children's sample HBV DNA level did not change. Average concentration of HBV DNA at that time was as high as $1.10 \times 10^{9}$ copies/ml. Two years of lamivudine therapy did not cause statistical significant changes $(p=0,87)$ in HBV DNA concentration when compared to value after one and half year of lamivudine treatment. Average concentration of HBV DNA at that time was $5.75 \times$ $10^{8}$ copies $/ \mathrm{ml}$

Therefore, after lamivudyne discontinuation in 21 $(77,8 \%)$ children observed increased level of HBV DNA compared to DNA level after two years after lamivudine therapy $(\mathrm{p}=0.002)$.

Only $4(14.8 \%)$ children manifested lower HBV DNA in blood sera, but still were considered as HBV 
Table 1. The total number of patients with mutation rt M204 V and rt M204 I.

\begin{tabular}{|l|c|c|c|c|}
\hline \multirow{2}{*}{ Type of mutation } & \multicolumn{3}{|c|}{ lime } \\
\cline { 2 - 5 } & $\begin{array}{c}12 \text { months } \\
\text { after treatment }\end{array}$ & $\begin{array}{c}18 \text { months } \\
\text { after treatment }\end{array}$ & $\begin{array}{c}24 \text { months } \\
\text { after treatment }\end{array}$ & after lamivudine discontinuation \\
\hline rtM204V & $4 / 27(14.8 \%)$ & $9 / 27(33.3 \%)$ & $9 / 27(33.3 \%)$ & $3 / 27(11.1 \%)$ \\
\hline $\mathrm{rtM} 204 \mathrm{I}$ & $3 / 27(11.1 \%)$ & $5 / 27(18.5 \%)$ & $8 / 27(29.6 \%)$ & $1 / 27(3.7 \%)$ \\
\hline
\end{tabular}

DNA positive. Thus, 2 (7.4\%) patients were characterized as HBV DNA negative. Average concentration of HBV DNA at that time of experiment was $1.16 \times 10^{10}$ copies/ml.

Logarithmic graph of average concentration of HBV DNA during and after lamivudine treatment have been presented on Fig. 1 .

\section{Evolution of hepatitis $B$ virus polymerase gene mutations during 2 years of lamivudine therapy and six months after lamivudine discontinuation}

According to sequence analysis, a lamivudine-resistant mutation developed in 7 (25.9\%) of 27 patients after 1 year of treatment. In all 7 (25.9\%) patients, the mutation occurred in the YMDD motif at reverse transcriptase position 204 (rt204; M204V/I). 4 (14.8\%) patients had substitution ATG $\rightarrow$ GTG whereas $3(11.1 \%)$ other children had substitution ATG $\rightarrow$ ATT. In two different patients, the YMDD mutation was combined with wild type of virus. Therefore, during treatment process wild type of HBV was replaced by dominant mutation in those patients. Our results didn't show any remarkable differences $(p=0.059)$ between number of patients with mutation in group I and II after one year of lamivudine therapy.

Therefore, after 1.5 year of lamivudine treatment we observed mutation at reverse transcriptase position 204 (rt204; M204V/I) in $14(51.8 \%)$ patients from group I. A significant difference $(p=0.0002)$ was observed between number of mutation in group I and II. Nine $(33.3 \%)$ children had substitution $\mathrm{ATG} \rightarrow \mathrm{GTG}$, and the other $5(18.5 \%)-\mathrm{ATG} \rightarrow \mathrm{ATT}$.

Two years of lamivudine treatment induced mutation in conservative motif at reverse transcriptase in 17 $(62.9 \%)$ children from group I.

A significant difference $(p=0.000002)$ were observed in number of mutation between two groups. Thus, six months after lamivudine discontinuation in $23(85.2 \%)$ YMDD mutation were replaced by wild type of HBV virus. Only 4 (14.8\%) patients displayed mutation at positions $\mathrm{rt} 204$. The total number of patients with mutation rt M204 V and rt M204 I have been presented in Table 1.

\section{Serological response}

Before lamivudyne treatment all of the 27 children had $\mathrm{HBeAg}$ and none of them had anti-HBe. After half year of treatment in $1(3.7 \%)$ patient from group I we observed seroconversion. After one year of lamivudine therapy in $3(11.1 \%)$ patients from group II and 2 (7.4\%) from group I anti-HBe were developed, therefore seroconversion observed just in one patient. After one and half year of lamivudine therapy $\mathrm{HBeAg}$ disappeared in 3 $(11.1 \%)$ patients ( 1 child from group I and 2 children from group II). Two years after treatment in $8(29.6 \%)$ children observed anti-HBe (6 children from group II and two from group I) - seroconversion noticed in 6 $(22.2 \%)$ cases ( 5 children from group II).

Therefore, half year after lamivudine discontinuation seroconversion was observed in $4(14.8 \%)$ children from group II. Reseroconversion on the other hand, appeared in 1 patient from group II after lamivudine discontinuation. HBV DNA concentration in this patient at that time was as high as $9 \times 10^{9}$ copies $/ \mathrm{ml}$, whereas 2 years after lamivudine therapy was $<10^{3}$ copies $/ \mathrm{ml}$ and at that time we observed seroconversion in $\mathrm{HBeAg} /$ anti-HBe (Table 2).

\section{Biochemical response}

ALT activity in total number of 27 patients did not show any significant differences during lamivudine treatment, and after lamivudine discontinuation. Changes in ALT in total 27 number of patients during 2 years and after lamivudine therapy have been presented on Fig. 2. Average activity of ALT $\pm \mathrm{SD}$ in total number of patients and in particular groups has been shown in Table 3.

\section{Discussion}

Chronic hepatitis B in children is mostly asymptomatic, but they are at life long risk for severe complications like cirrhosis and HCC. Treatment is considered to suppress the virus and to prolong the survival by preventing the complications. Beneficial treatment options for children are interferon-alpha (IFN-alpha) with antiviral, antiproliferative and immuno-modulatory effects and lamivudine (LAM) which inhibits replication of HBV and increases cellular immune response [7]. 
Table 2. Serological results. $* \mathrm{HBe}^{+}$- patients with presence of $\mathrm{HBe}$ in blood serum, $\mathrm{HBe}^{-}$- patients with absence of $\mathrm{HBe}$ in blood serum, Anti-HBe ${ }^{+}-$patients with anti $\mathrm{HBe}$ in blood serum

\begin{tabular}{|c|c|c|c|c|c|c|c|c|c|}
\hline \multirow{3}{*}{ Time of treatment } & \multicolumn{9}{|c|}{ Number of patients } \\
\hline & \multicolumn{3}{|c|}{$\begin{array}{l}\text { Total * } \\
(n=27)\end{array}$} & \multicolumn{3}{|c|}{$\begin{array}{l}\text { Group I } \\
(\mathrm{n}=18)\end{array}$} & \multicolumn{3}{|c|}{$\begin{array}{l}\text { GroupII } \\
(\mathrm{n}=9)\end{array}$} \\
\hline & $\mathrm{I \amalg} \mathrm{c}^{\prime}$ & $1 \amalg \mathrm{c}^{-}$ & Anti $I \amalg \mathrm{e}^{\prime}$ & IШ $\mathrm{c}^{\prime}$ & $1 \amalg \mathrm{c}^{-}$ & Anli IE' & IШ $\mathrm{e}^{\prime}$ & $1 \amalg \mathrm{c}^{-}$ & Anti $I \amalg \mathrm{c}^{\prime}$ \\
\hline Before treatment & 27 & 0 & 0 & 18 & 0 & 0 & 9 & 0 & 0 \\
\hline $\begin{array}{l}\text { After } 6 \text { months of } \\
\text { treatment }\end{array}$ & 26 & 1 & 1 & 17 & 1 & 1 & 9 & 0 & 0 \\
\hline $\begin{array}{l}\text { Altcr } 12 \text { months of } \\
\text { treatment }\end{array}$ & 26 & 1 & 5 & 17 & 1 & 2 & 9 & 0 & 3 \\
\hline $\begin{array}{l}\text { After } 18 \text { months of } \\
\text { treatment }\end{array}$ & 24 & 3 & 5 & 17 & 1 & 2 & 8 & 2 & 3 \\
\hline $\begin{array}{l}\text { After } 24 \text { months of } \\
\text { treatment }\end{array}$ & 21 & 6 & 8 & 17 & 1 & 2 & 4 & 5 & 6 \\
\hline $\begin{array}{l}\text { After } 6 \text { months of } \\
\text { lamivudine } \\
\text { discontinuation }\end{array}$ & 22 & 5 & 7 & 17 & 1 & 1 & 5 & 4 & 6 \\
\hline
\end{tabular}

Table 3. Average activity of ALT \pm SD ( SD - standard deviation) in total number of patients and in particular groups.

\begin{tabular}{|l|c|c|c|c|c|c|}
\hline \multirow{2}{*}{ Time of treatment- $\Lambda$ I T activity } & \multicolumn{2}{c|}{ Total } & \multicolumn{2}{c|}{ Group I } & \multicolumn{2}{c|}{ Group II } \\
\cline { 2 - 7 } & average & SD & average & SD & average & SD \\
\hline Before treatment & 64.56 & 46.04 & 71.22 & 45.01 & 51.22 & 47.80 \\
\hline 0.5 year after treatment & 39.15 & 15.61 & 43.65 & 15.65 & 30.67 & 12.13 \\
\hline 1 year after treatment & 35.44 & 37.61 & 41.67 & 44.64 & 23.00 & 10.09 \\
\hline 1.5 year after treatment & 32.65 & 17.75 & 34.67 & 17.91 & 28.13 & 17.66 \\
\hline 2 years after treatment & 44.85 & 36.59 & 46.11 & 40.35 & 42.33 & 29.66 \\
\hline 0.5 year after lamivudine discontinuation & 51.37 & 47.79 & 51.72 & 28.86 & 50.67 & 75.19 \\
\hline
\end{tabular}

Lamivudine is well tolerated and significantly reduces HBV DNA level [8]. In our study all 27 children had high level of HBV DNA before lamivudine treatment. After half year of lamivudine therapy all patients had significantly lower HBV DNA level when compared to level of HBV DNA before treatment $(p=0.00001)$. Although, next months of treatment showed that HBV DNA level increased in some patients. Six months after lamivudine discontinuation HBV DNA level in $21(77.8 \%)$ children was over than $10^{5}$ copies $/ \mathrm{ml}$. In $2(7.4 \%)$ cases we observed virological response. Average concentration of HBV DNA at that time of experiment was $1.16 \times 10^{10} \mathrm{copy} / \mathrm{ml}$.

These children cases also showed, that long term lamivudine therapy could induce emergence of lamivudine resistant mutations in chronic hepatitis B patients, but discontinuation of treatment could induce reemergence of wild type of $\mathrm{HBV}$ with prior lamivudine resistance.
However, lamivudine resistance associated with mutations in the polymerase gene, particularly in rtM204I/V known as YMDD mutant, occurs at a rate of $14 \%-30 \%$ annually $[9,10]$. Although, genetic mechanism of lamivudine resistance is known, the distant results of lamivudine treatment in children still remain unclear. In our study lamivudine-resistant mutation developed in $7(25.9 \%)$ of 27 patients after 1 year of treatment. In addition, lamivudine-resistant mutations were suppressed after treatment discontinuation. Therefore, YMDD mutations were found in 4 (14.8\%) of the 27 patients after lamivudine discontinuation and in $23(85.2 \%)$ children mutations were replaced by wild type of HBV.

Sokal et al. [5] consider that treatment should be continued, for up to 36 months, until VR, with or without seroconversion, is achieved. In view of the poor long-term response, they recommend that treatment is discontinued if YMDD mutations emerge. It is likely 


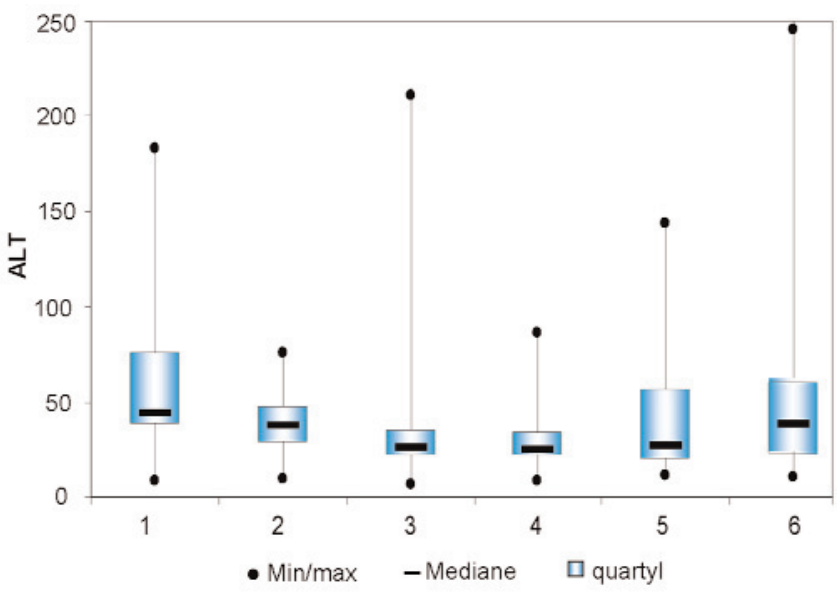

Fig. 2. Changes in ALT in total 27 number of patients during 2 years and after lamivudine therapy: 1 - before treatment; 2 - half a year after treatment; 3 - year after treatment; 4 - year and a half after treatment; 5 - two years after treatment; 6 - six months after lamivudine discontinuation.

that most patients will tolerate the discontinuation of therapy in view of their mild underlying disease, and that they will probably return to their pretreatment disease status. Sokal et al. concluded also that despite the fact that children response to lamivudine treatment, more than $60 \%$ of them did not meet the study endpoint. Their observation suggests the need for selection of candidates that will benefit from treatment, and secondly the need for new therapeutic strategies, such as combination antiviral therapy, that will provide more potent viral suppression, and present a higher barrier to the emergence of resistance.

Jonas MM et al. [11] found that treatment of chronic hepatitis B with lamivudine for one year is safe in children and is superior to placebo, although neither approach is highly efficacious. Efficacy may be improved by selecting patients whose alanine aminotransferase value is at least twice the upper limit of the normal range. Jonas MM et al. suggest also, that virologic and biochemical responses achieved with lamivudine therapy are as durable as spontaneous responses, at least for the first six months. Although, there are data to suggest that further therapeutic responses are achieved with longer therapy, the development of genotypic resistance may limit the benefits of extended therapy, since the long-term outcome of chronic hepatitis B in children with lamivudine-resistant mutants remain unknown.

\section{References}

[ 1] World Health Organization. Hepatitis B. Fact sheet no. 204. Geneva, Switzerland: World Health Organization, October 2000.

[2] Hsieh CC, Tzonou A, Zavitsano X, Kaklmani E, Lan SJ, Trichopoulus D. Age at first establishment of chronic hepatitis B virus infection and hepatocellular carcinoma risk: a birth order study. Am J Epidemiol. 1992;136:1115-1121.

[3] Lok A, McMahon BJ. AASLD Chronic hepatitis B: update of recommendations. Hepatology. 2004;39:857-861.

[4] Liaw YF, Sung JJ, Chow WC et al. Lamivudine for patients with chronic hepatitis B and advanced liver disease. $N$ Engl $J$ Med. 2004;351(15):1521-31.

[5] Sokal EM, Kelly DA, Mizerski J, Badia IB, Areias JA, Schwarz KB, Vegnente A, Little NR, Gardener SD, Jonas MM. Long-term lamivudine therapy for children with HBeAg-positive chronic hepatitis B. Hepatology. 2006;43(2):225-32.

[6] Poch O, Sauvaget I, Delarue M, Tordo N. Identification of four conserved motifs among the RNA-dependent polymerase encoding elements. EMBO J. 1989;8:3867-74.

[ 7] Kansu A. Treatment of chronic hepatitis B in children. Recent Patents Anti-Infect Drug Disc. 2008;3(1):64-9.

[8] Dienstag JL, Schiff ER, Wright TL, Perrillo RP, Hann HW, Goodman Z, Crowther L, Condreay LD, Woessner M, RubinM, Brown NA. Lamivudine as initial treatment for chronic hepatitis B in the United States. N Engl J Med. 1999; 341:1256-1263.

[ 9] Allen MI, Deslauriers M, Andrews CW, Tipples GA, WaltersKA, Tyrrell DL, Brown N, Condreay LD. Identificationand characterization of mutations in hepatitis B virusresistant to lamivudine. Lamivudine Clinical InvestigationGroup. Hepatology. 1998;27:1670-1677.

[10] Lok AS, Lai CL, Leung N, Yao GB, Cui ZY, Schiff ER, DienstagJL, Heathcote EJ, Little NR, Griffiths DA, Gardner SD, CastigliaM. Long-term safety of lamivudine treatment in patients withchronic hepatitis B. Gastroenterology. 2003;125: 1714-1722.

[11] Jonas MM, Kelley DA, Mizerski J et al. Clinical Trial of Lamivudine in Children with Chronic Hepatitis B. $N$ Engl $J$ Med. 2002;346:1706-1713.

Submitted: 31 August,2009 Accepted after reviews: 20 January, 2010 